\title{
State Formation in Romania: A Successful Story of Nationalism and Centralization, 1848-1864
}

\author{
Sebastian I. BURDUJA \\ The Bucharest University of Economic Studies, Romania \\ sebastian.burduja@gmail.com
}

\begin{abstract}
Historically, the Romanian state's formation began roughly with the Revolution of 1848, the first concrete, major movement for the unification of the Romanian principalities. Following decades of building both internal and external support for the idea of a single Romanian state, Moldavians and Wallachians benefited from a favourable global context and accomplished the union of 1859. This was based on the Paris Convention of 1858, which acknowledged Romanian unionist ideals. This de jure unification was, however, only the first stage in the process of the Romanian state's formation. An extensive and multifaceted development of administrative centralization comprised the second stage of state formation, which corresponds to the de facto unification. Considering the two distinct phases of Romanian state formation, 170 years after the first step toward Romanian unification and 100 years after its full expression in 1918, this article argues that the two factors that best account for the successful formation of the Romanian state are nationalism and centralization.
\end{abstract}

Keywords: state formation; nationalism; centralization; unification; Romania;

JEL Codes: F52; F59; O52;

DOI: http://doi.org/10.24818/ejis.2018.07

\section{Introduction}

In the year 1858, history witnessed the unlikely formation of a new state at the gates of the Ottoman, Habsburg, and Russian empires: The United Principalities of Moldavia and Wallachia. ${ }^{1}$ Following several decades of nationalist movement strongly militating for their unification, Moldavians and Wallachians took advantage of a favourable global context and accomplished the union of their respective principalities. This was called also the politics of the fait accompli - an accomplished and irreversible fact, despite potential international opposition. What are the key factors that explain Romania's 1859 unification, and how do they compare with typical models of state formation?

The Paris Convention of 1858 acknowledged Romanian unionist aspirations and formally recognized the new state, after intensive negotiations between the major powers present (Dumitru, 2010). Broadly, the Ottomans, the Austro-Hungarians, and the British tended to oppose full unification, for their own reasons: The Ottomans were afraid to lose their influence over Moldavia and Wallachia; the British were interested in maintaining the Ottomans' strength; the Austro-Hungarians feared that the Romanian population of Transylvania would call for unification too. On the other side, the French - back by the

\footnotetext{
${ }^{1}$ The Habsburg Empire imposed the name of "The United Principalities of Moldavia and Wallachia" at the Paris Convention of 1858. In 1862, the state was entitled "Romania," according to Romanian unionists' initial request.
} 
Russians, for a multitude of reasons - became the staunchest supporters of the formation of a single Romanian state.

This de jure unification was, albeit extremely difficult to accomplish, only the first stage in the process of state formation in Romania. An extensive and multifaceted development of administrative centralization comprised the second stage of state formation, which corresponds to the de facto unification of the principalities of Moldavia and Wallachia. Considering these two distinct phases of Romanian state formation, this article argues that there are two factors that best account for this process: (i) nationalism and (ii) centralization.

\section{Tilly's Model vs. the Romanian State's Formation}

In Weberian terms, state formation can be described as the process of constructing "a compulsory organization with a territorial basis [whose] claim [...] to monopolize the use of force is essential" (Weber, 1978). In Romania's case, the two key elements of the Weberian definition - territorial basis and monopoly over the legitimate use of force match the two respective crucial stages of state formation, as described above.

While nationalism produced the formal unification that granted a territorial basis for the new state, the subsequent process of centralization provided exclusive monopoly over coercive means over the unified territory. Historically, the formation of the Romanian state began roughly with the Revolution of 1848, the first concrete and violent nationalist movement for unity, and ended with the Constitution of 1864, which concluded the country's political centralization process. This particular pattern of state formation broadly contradicts Charles Tilly's well-known principle of "state making and war making" (2004). Tilly argued that wars trigger an acute need for resources, which are acquired through borrowing or by extracting more from the population. At the same time, there is a need for central protection against threats. As Spruyt put it, "Tilly's account thus melds a description of a broad exogenous change - the change in the nature of warfare-with a contractarian explanation for the rise of central authority...central authority provided protection in exchange for revenue" (2011). As a result, the state's administrative and bureaucratic apparatus develops, and coercion increases.

Still, the current article shows that the Romanian state's formation, including the Unification of 1859 , functions under a distinct mechanism, as illustrated by the following figure.

Figure 1. Proposed model for Romania's state formation

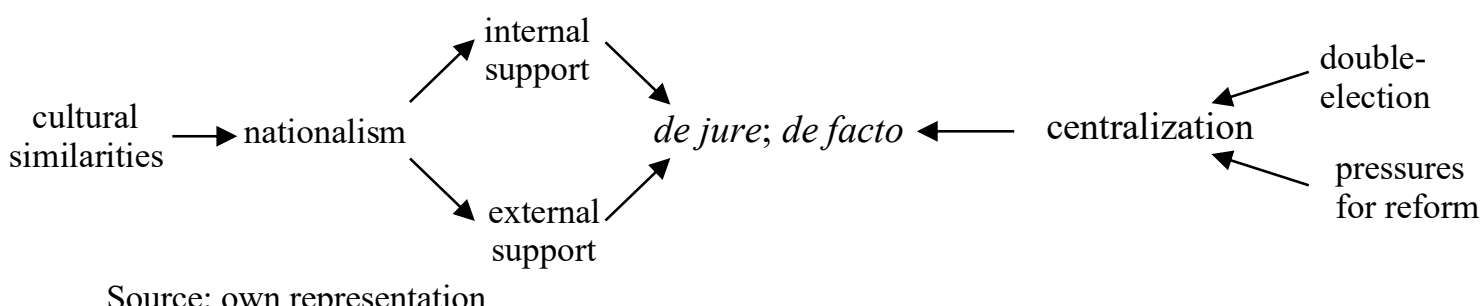


In fact, Tilly's starting point - existence of an external threat - does not apply to Moldavia or Wallachia, since the two Principalities had not participated in any wars by themselves since medieval times; moreover, after unification, Romania remained peaceful for another 19 years, until the War for Independence of 1877. Hence, Tilly's causal chain breaks from the start and one must seek other factors accountable for the Romanian state's formation. This article argues that both nationalism and centralization are accountable for the unification process.

\section{Nationalism for De Jure Unification}

Nationalism had the most decisive influence on Romania's de jure formation, given that it preceded the formal unification of 1858. On a foundation of shared culture and language, nationalism fuelled both internal and external support for the unionist creed. But what is nationalism, and how can it be best defined in the context of this article? Multiple definitions exist in the specialized literature. Haas puts it in these simple terms: "[nationalism is] a belief held by a group of people that they ought to constitute a nation, or that they already are one" (1986). Critics of this stance point to the fact that nationalism has to go beyond a mere belief to include the actions and processes stemming from that belief. One of the most popular definitions in the specialized literature is the one provided by Gellner, who describes nationalism as a "political movement designed to make or strengthen a state whose boundaries are commensurate with a nation" (1997, p.3).

In a similar vein, in his extensive review of the term's definitions, Barrington shows that "nationalisms share two features: (1) they define, at least roughly, the territorial boundaries that the nation has a right to control and (2) they define the membership boundaries of the population that makes up the nation-the group that deserves this territorial control and that is entitled to the supreme loyalty of other members of the collective" (1997, p.4). Both elements are important. A nation, self-defined by certain criteria, requires a clearly established territory over which it lays the claim of territorial control -i.e., a legitimate use of force, in Weberian terms.

This is also in line with Benedict Anderson's definition of the nation as "an imagined political community, imagined as both inherently limited and sovereign" (2006, p.6). The community is imagined, because its members can never know or meet all the other fellowmembers, but they still have the image of a single community with shared characteristics. In addition, the two fundamental elements of the imagined political community are "inherently limited" and "sovereign." Inherently limited refers to the fact that nationalists do not want to control the entire world, but rather only that territory that is commensurate with their imagined political community. Sovereign is to be interpreted in the same Weberian register, as the state's exclusive monopoly over the use of violence.

Based on these definitions, one can argue that in the Principalities the foremost stake was making a state commensurate with the imagined Romanian community, a concept incorporating both Moldavians and Wallachians (as well as Romanians in Transylvania and elsewhere). As a matter of fact, Romanian nationalism harks back to at least 1838, when the National Party in Wallachia set forth as its ultimate aim "[the] confederation or union with Moldavia" (Campbell, 1971). Campbell further argues that "the National Party had its 
Moldavian counterpart, and sentiment in favour of union was widespread" (1971). This is confirmed by later accounts by several French diplomatic representatives active in the two principalities around 1859: "in Wallachia everybody was unionist" (Consul L. Beclard, qtd. Oncescu, 2007).

One can explain the emergence of Romanian nationalism by looking at cultural similarities between people in the Principalities, which originate in the Roman conquest of Dacia in 106 A.D. From the Dacian-Roman mixture emerged a unitary nation with a similar dialect to Latin, but historical causes like the increase of Ottoman power led to its fragmentation into medieval states. In 1600, Prince Michael the Brave succeeded for the first time in history in uniting the Romanian Principalities under his command - albeit brief, this union was heralded subsequently, particularly by historian and revolutionary leader Nicolae Bălcescu and the other ,forty-eighters”, as a defining historical moment pointing to common aspirations for the unification of all territories inhabited by Romanians. Indeed, all these examples suggest that Moldavians and Wallachians shared many cultural and historical defining features, which represented the foundation for the nationalist movement of the $19^{\text {th }}$ century.

In struggling toward building internal support for the unification process, nationalists emphasized these common historical and cultural roots. Combining propaganda and history, nationalist historians had "perhaps the greatest contribution [...] to the growth of nationalism" (Campbell, 1971). In a popular manifest, nationalist leader Mihail Kogălniceanu confessed that he regarded as his fatherland "all that territory where Romanian is spoken, and as national history, the history of all Moldavia and that of Wallachia" (1921, p.79). This struggle toward proving the existence of a common culture is in keeping with Gellner's definition of nationalism, which maintained that "similarity of culture is the basic social bond" (1997, p.4). This is also aligned with Anderson's concept of imagined community, as described earlier (2006).

The nationalist rhetoric won the support of many intellectuals and wealthy landowners at the time. Trying to build broader support for unification, unionists designed their own version of Romanian nationalism, allowing "only members of the appropriate culture to join the unit" (Gellner, 1997, p.4). Thus, a key appeal for peasants and workers to join the nationalist movement and its calls for unification of the principalities was strong opposition toward foreign elites that were labelled as oppressive elements, exploiting the resources that belonged to the people of Moldavia and Wallachia. Romanian personalities perfectly fit the nationalist leader prototype, as defined by the specialized literature, providing the masses with a sense of identity and always proving ready to "proclaim national unity [and] denounce all enemies" (Snyder, 1976). Certainly, nationalism addressed all classes among the Romanian population, and succeeded in creating strong unionist feelings across society. This internal support was necessary - but not sufficient - for both the formal unification of 1858 and the centralization process following that.

Additionally, Romanian nationalists managed to receive wide external approval of unification (Jianu, 2011). Nationalism had become a key factor in producing a continuous turmoil in Eastern Europe, which brought the aspirations of Romanians to the attention of powerful European states, most prominently France, with whom the principalities of Moldavia and Wallachia, mainly through their elites, maintained close diplomatic relations. 
Furthermore, after the unsuccessful Revolution of 1848, many nationalist leaders avoided persecution by seeking refuge in countries like France and Italy. Subsequently, they launched a vast diplomatic offensive designed to get the powerful countries' support for Romanian unionism. Among many other initiatives, Nicolae Golescu urged Napoleon III to help Romanians unite, even under a French flag: "You would have there more than a colony, more than a fortress" (qtd. in Campbell, 1971). There was an intensive effort to promote the cause of unification abroad, at both national and even local levels. For example, Jianu describes Brătianu's and Golescu's attempts to influence public opinion in Manchester and Liverpool, where "they felt that they had to appeal to the enlightened selfinterest of the British industrial and commercial classes" (2011). As a consequence, Brătianu published public responses to the Russian propaganda trying to justify an invasion and occupation of Moldavia and Wallachia for diplomatic and religious reasons against the Ottomans.

After such actions by Romanian elites abroad, and considering the strong internal support for unification, the issue of the principalities had to be resolved at the international level. Following the Crimean War, Western powers decided to discuss the prospects of unification and, after a referendum proving Romanians' popular support for the union, they agreed to the unification in the Paris Convention of 1858.

\section{Centralization for De Facto Unification}

The most decisive factor in the de facto state formation in Romania was arguably the second one - centralization, ultimately leading to the state's exclusive monopoly over the use of legitimate force. It is important to note that, unlike the de jure unification of 1859, which can be considered complete at a specific point in time, centralization was a process, subsequent to unification, and was pursued over a longer period of time, including domestic reforms. These measures were often taken in the absence of continuous external approval, signalling the beginning of a functional independent state and the continuation of the fait accompli policy.

The concept of centralization describes the concentration of power under a single central control. The Paris Convention of 1858 for the "definitive organization of the United Romanian Principalities" effectively created a new constitution for the united principalities, which "were supposed to be separate entities [with] [...] duplication of parallel institutions" (Michelson, 1998). Hence Moldavia and Wallachia each had, at least initially, its own prince, government, and legislative body, all remaining under formal Ottoman sovereignty, though they would be "free to manage themselves." ${ }^{2}$ The only common institutions among the two Principalities were as follows: a legislative body that was entitled The Central Commission, headquartered in Focșani and including sixteen paid members, appointed or elected by the respective rulers and parliaments of the principalities; and The Supreme Court, also based in Focșani (Neagoe, 1986). ${ }^{3}$

\footnotetext{
2 The original text of the 1858 Paris Convention is available online: https://statuldacia.files.wordpress.com/2016/01/conventia-de-la-paris-din-1858-legea-fundamentala-aromaniei.pdf

${ }^{3}$ The Central Commission was a mixed Moldavian-Wallachian legislative body that decided over matters concerning both Principalities. It was dominated by a conservative, secessionist group.
} 
Although its purpose was to satisfy unionist aspirations and at the same time temper the Habsburgs and Ottomans' reticence for a powerful state at their borders, such provisions ensured a limited degree of centralization, along with a doubling of key state institutions. They only managed to produce "a hybrid mixture of union and separation" (Xenopol, 1985). Two key factors further encouraged administrative centralization and implicitly the de facto formation of the Romanian state: a double election of the same leader in both principalities and the incredibly high pressures for radical economic and social reforms.

First, the centralization process was facilitated by a "double election" in Moldavia and Wallachia in 1859. Nationalist politicians dominated the Elective Assemblies in the two Principalities and, when the time came, fervently militated for the election of the same Prince. Indeed, on January 24, 1859, Colonel Alexandru Ioan Cuza became an elected prince of both Moldavia and Wallachia. This unexpected turn of events concentrated the executive power in the hands of a single prince ("gospodar", in Romanian), with relatively strong powers based on the text of the 1858 Paris Convention, including the ability to issue and strengthen laws, make the budget and present it to parliament, dissolve parliament, etc. This therefore concluded the first step of the administrative centralization process. It is interesting to note that the double election was not the result of some carefully planned scheme. Per multiple historical accounts, Cuza's election was unpredictable and ad-hoc, in line with the Romanian political stance of fait accompli toward the great external powers of the time (Oncescu, 2007).

A dedicated unionist, Prince Cuza promoted over the next few years sweeping reforms that were meant "to unify the two countries, to serve as a basis of the centralized organization of the new state" (Berindei, 1984). Beside these nationalist arguments and the need to provide a monopoly over the use of force in both principalities, the Prince had other incentives for promoting administrative centralization. The additional factors that facilitated centralization were the principalities' backward economies, peasants' pressure for a favorable solution to the agrarian problem, and secessionist discontent against the new state.

In this context, the only way that the new state could survive these challenges was by implementing the much-needed reforms at a fast pace and quickly achieving economic growth. However, the Paris Convention's decentralized model proved incapable to serve Cuza's praiseworthy goals and the needs of the principalities. From the beginning, the prince faced an extremely complicated apparatus of legislature, taking into account the need to go through all the required checks. Any law proposal needed the approval of both legislatures in Moldavia and Wallachia, of the Prince, and of the Central Commission, an institution with a strong secessionist majority that opposed many reforms. Any law of "general interest," including all laws pushing forward the unification process, as required specifically by the text of the Paris Convention, had to be initiated by the Central Commission, and get the approval of each parliamentary assembly. The statistics speak for themselves: in two years, this intricate legislative system only passed six legal projects.

Often times, Cuza used the extensive powers granted by the Convention and promulgated many administrative reforms by decree. The prince proceeded to unify the Customs Service and Penitentiary Service. More importantly, Cuza united the Moldavian and Wallachian Police Departments, providing the state with a monopoly over the legitimate use of force. In 1860, Cuza continued the process of administrative centralization of several ministries like the Health and Education departments. Bucharest became the new capital of the single 
state and January $24^{\text {th }}$ was celebrated nation-wide as the national day. Frequently, the prince used to delegate authority in Wallachia to Moldavians, while in Moldavia he would send Wallachians, leading to an exchange of elites (Platon, 1993). In 1862, Cuza completes the unification of the two legislative bodies under a single Parliament.

Despite the simplification of procedures for promulgating laws, the conservative forces in the new parliament only adopted seven proposals out of 68 projects for reforms submitted in the years 1862-1863. Consequently, prince Cuza decided to dissolve the parliament and assume complete powers, speeding up the promulgation of reforms and pushing forward the complex process of administrative and political centralization.

The 1864 Constitution, proposed by prince Cuza and voted into force by a popular referendum, concluded the new state's formation process. It imposed a highly centralized system that managed to achieve economic growth, solve the agrarian problem by granting property rights to the large peasant population, expand voting rights, and resist secessionist pressures from within. It is important to note that such changes were not formally approved by the foreign powers who had signed the 1858 Paris Convention. Time and again, prince Cuza and the Romanian political elites of the time marched forward on the principle of fait accompli.

Centralization was therefore the second critical factor in the formation of the Romanian state. It started with the effective double election of prince Cuza in both Moldavia and Wallachia and continued with a series of sweeping administrative and political reforms. First within the strict boundaries set by the 1858 Paris Convention, in practice these reforms went far beyond what the convention's signatories envisioned. In February 1866, Cuza was forced to abdicate the throne and leave the country, by political forces favorable to the idea of a new foreign price who could guarantee the consolidation of the new state (Giurescu 2000). Even so, after his seven-year rule, the new Romanian state featured a new centralized model of political administration, which proved to be a solid enough foundation for the survival of the newly formed state.

\section{Conclusions}

The current article has shown that the process of state formation in Romania is without a doubt an exception to Tilly's theoretical model of state formation. While Tilly presumes that states are formed as a result of an external military threat, whereby advances in war techniques require greater centralization, administration, resource extraction, and centralized protection of the population, the unification of the Moldavian and Wallachian principalities has followed a different logic. Indeed, this was a rather late process of the $18^{\text {th }}$ century, which can be related to the formation of the German and Italian formations through the same method of unification.

In the absence of an external threat, as presumed by Tilly, the factors that explain the Romanian state's formation are shown to be nationalism and centralization. Nationalism is based on cultural similarities between the Romanian inhabitants of Moldavia and Wallachia (as well as other provinces later united with Romania), and - through a complicated, lengthy process - successfully garnered both internal and external support for the idea of a unified Romanian state. This created the conditions for de jure unification based on the 
provisions of the 1858 Paris Convention, but the de facto formation of Romania truly happened in subsequent years through prince Cuza's reforms. It is beyond this article's scope to establish whether the true aim of the reforms was the concentration of power into fewer hands or if indeed centralization was a means to an end - the more rapid adoption of badly needed reforms, which had to pass in order to protect the survival of the new state. What matters for the purposes of the current assessment is the fact that in Romania's specific case the processes of state formation and centralization of power are effectively inseparable.

At the same time, the importance of timing should not be understated, of course. Beyond the actions of Romanian patriots, the formation of the Romanian state depended on a favourable regional context that allowed Romanian elites and their allies to exploit and pit against each other the goals and ambitions of neighbouring powers. There is a vast literature proving the fundamental role played by France and Napoleon III in the final draft of the Paris Convention. It also helped that the Russian Empire sought at the time to side with the French in opposition to the Austro-Hungarians and the Ottomans. It is also true that timing matters throughout history, not just for the formation of the Romanian state.

All else being equal, nationalism and centralization are indeed the driving forces of both de jure and de facto unification. Although this brief analytical model suggests an approach only to Romania's particular case, further research is needed to establish its consistence in many other East European states where Tilly's model is partially or fully inapplicable.

\section{References:}

Anderson, B. 2006. Imagined Communities: Reflections on the Origin and Spread of Nationalism. London: Verso.

Barrington, L. 1997. "Nation" and "Nationalism": The Misuse of Key Concepts in Political Science. PS: Political Science \& Politics, 30(4), 712-716.

Berindei, D. 1984. Unirea Principatelor si puterile europene [Unification of the Principalities and European Powers]. Bucharest: Editura Academiei, p. 156.

Campbell, J. 1971. French Influence and the Rise of Romanian Nationalism. New York: Arno Press \& The New York Times, pp. 10, 49, 51, 161.

Dumitru, D. 2010. Mare Britanie și Unirea Principatelor Române [Great Britain and the Unification of Romanian Principalities]. Chișinău: Pontos, pp. 115-123.

Gellner, E. 1997. Nationalism. New York: New York University Press.

Giurescu, C. 2000. Viața și opera lui Cuza Vodă [The Life and the Work of Prince Cuza]. București: Editura Curtea Veche, p. 308.

Haas. Ernst. 1986. "What is Nationalism and Why Should We Study It?" International Organization 40(3): 707-34.

Jianu, A. 2011. A Circle of Friends. Romanian Revolutionaries and Political Exile, 1840-1859. Leiden: Koninklijke Brill NV.

Kogalniceanu, M. 1921. Opere [Literary Works]. Craiova: Cartojan.

Michelson, P. 1998. Romanian Politics, 1859-1871. From Prince Cuza to Prince Carol. Oxford: Center for Romanian Studies, p. 34.

Neagoe, S. 1986. Istoria Unirii romanilor [The History of Romanians' Unification]. Bucharest: Editura Stiintifica si Enciclopedica, p. 499.

Oncescu, Iulian I. 2007. "The French Consular Reports: a Consistent Source of Information on the Romanian Principalities from 1856 to 1859," in Stanciu I. and Miloiu S. (eds.), Europe as Viewed from the Margins. Târgoviște: Editura Cetatea de Scaun. 
Platon, G. 1993. Cum s-a infaptuit Romania moderna [The Emergence of the Modern Romanian State]. Iasi: Editura Universitatii Al. I. Cuza, pp. 94-95.

Snyder, L. 1976. Varieties of Nationalism: A Comparative Study. New York: Holt, Rinehart and Winston, p. 12.

Spruyt, H. 2011. "War, Trade, and State Formation," in Goodwin, R. (ed.). The Oxford Handbook of Political Science. Oxford: Oxford University Press, p. 5.

Tilly, C. 2004. Coercion, Capital, and European States. Cambridge: Blackwell, p. 67.

Weber, M. 1978. Economy and Society. An Outline of Interpretative Sociology. Berkeley:

University of California Press, p. 56.

Xenopol, A. 1985. Istoria romanilor [Romanians' History]. Bucharest: Editura Stiintifica si Enciclopedica, p. 234. 